\title{
SOCIETY OF EUROPEAN NEMATOLOGISTS
}

$\mathrm{A}^{\mathrm{T}}$

$T$ the invitation and under the presidency of Prof. J. van den Brande, the sixth international nematology symposium of the Society of European Nematologists was held during July 24-28, 1961, at the State Agricultural College in the ancient and beautiful city of Ghent. From some twenty-seven countries came about 140 participants, the largest contingents being those from Belgium (thirty-three), Great Britain (thirty, after deducting four for overseas students), Germany, West and East (nineteen), and Netherlands (seventeen).

After the inaugural presidential address and a stimulating special lecture by Prof. de Coninck on "Problems of Systematics and Taxonomy in Nematology today," there followed some fifty papers, grouped after the first day under two simultaneous sections, and each ostensibly limited to $20 \mathrm{~min}$., including time for discussion.

Lack of space precludes a reference to every paper, but some of the trends and highlights can be briefly indicated.

In the field of taxonomy a paper by B. G. Chitwood (presented in his absence by A. L. Taylor) described and illustrated photographically the holotype and allotype specimens of most of the recognized Meloidogyne species and sub-species. These specimens were selected in 1960 by a committee of the American Phytopathological Society. Chitwood regards these taxa as possibly polyphyletic, originating as repetitive mutants ; at least one (M. javanica javanica) is probably a defective triploid.

W. C. Clark commented on the variability and accuracy of linear measurements used in systematics, and of ratios based on them. The de Man ratios, based on total length, are of little value when the latter is highly variable; also, they presuppose absence of allometric growth. H. Gysels showed that in Panagrellus silusiae post-embryonic growth is in fact allometric with respect to length: moreover, in the expression $y=K x^{a}$, the index may change at different stages in the life cycle.

Among matters of life-history and biology, A. M. Shepherd showed that Heterodera göttingiana larvæ emerged from eysts in soil, in the presence of a host, even more readily than $H$. rostochiensis, but could not be made to emerge in vitro. In tissue-culture experiments with Meloidogyne, M. L. Schuster and R. M. Sandstedt found that movements of larvæ were consistent with a random walk and accidental contact with roots rather than with an attraction mechanism. W. H. Lavallee and R. A. Rhode, on the other hand, interpreted the rapid concentration of Pratylenchus penetrans around a host at one end of a box as due to attraction.

The orientation of Ditylenchus dipsaci to physical stimuli was discussed by H. R. Wallace : in gradients of temperature, moisture, and size of sand particles, the worms preferred $10^{\circ} \mathrm{C}$., high moisture, and fine sand.

The feeding mechanisms of Rhabditids and Tylenchids were interestingly compared in a film by C. C. Doncaster. The movements of dye globules and air bubbles through the œsophagus were analysed, the bubbles showing change in size with pressure. $\mathrm{H}_{\Theta}$ also showed a film on nematode predators.
The geographical or topographical distribution of nematode populations was discussed in several papers. M. Ritter was able to correlate the distribution of species of Meloidogyne in France with climatic zones. J. de Maeseneer reported on the distribution of some of the chief migratory root nematodes in Belgium. E. Gadea gave data on the free-living nematodes of freshwater and moss biotopes in Spain. B. Weischer has made the ecologically interesting discovery of two species of Desmoscolecidae in vineyard soils from a small area centred on Bad Ems : the point is that most other species of this family are marine. A. B. Oteifa usefully summarized the chief plant nematodes of crops in Egypt.

Changes in nematode populations were dealt with by S. Stemerding, who counted Tylenchorhynchus dubius and Rotylenchus robustus in weekly samples from a monoculture of peas. R. Gair et al. found differences between varieties of spring barley in their effect on rate of increase of Heterodera avenae. M. Oostenbrink presented the results of examining numerous samples from meadows and arable land in the Netherlands. It is clear that the heaviest populations of nematodes come from the grass/clover crop from meadows. Many of these nematodes are plant parasites and are important in two ways: some are harmful to the grass/clover crop itself, and some become harmful on arable crops when the meadow is ploughed. K. Kuiper is tracing the gradual invasion of new polder-soils from the Zuider Zee area by plant nematodes, and the factors responsible for this invasion.

In the field of pathology, H. Goffart has shown that one effect of Ditylenchus dipsaci in sugar beet is to increase the content of reducing sugars; this also occurs with $D$. destructor in nutrient-agar cultures and to a smaller degree with Heterodera rostochiensis. The effect is ascribed to enzyme action from the œsophageal glands.

The importance of nematodes as vectors of virus pathogens was stressed by $R$. S. Pitcher. All the known cases belong to the Dorylaimoidea and are of two types: some 'ring-spot' viruses carried by nematodes of the Longidorinae, and tobacco rattle virus carried by Trichodorus. H. H. Sol showed that $T$. pachydermis appears to be the only transmitter, nematodes extracted from infected soil retaining the virus for at least three weeks.

An interaction between Verticillium albo-atrum and Pratylenchus penetrans has been shown by W. B. Mountain and C. D. McKeen, the nematode being more prevalent in the presence of the fungus.

L. Roguska-Wasilewska found that Heterodera schachtii inhibited the respiration of rape far more than did the saprophagous Eucephalobus elongatus.

Other disease situations included: Ditylenchus dipsaci increasingly causing collar-rot of beet in Switzerland (A. Savary); D. radicicola of Dutch strain damaging Poa annua but not barley, whereas the Swedish strain behaves in the reverse manner (J. J. s'Jacob); Radopholus similis causing root-rot in banana in New South Wales (C. D. Blake).

Numerous papers dealt with control methods. Outstanding were a tabulated compilation of reported crop-yield increases as a result of using nema- 
ticides in the United States, comprising 853 comparisons (A. L. Taylor), and a succinct account of the way in which Heterodera rostochiensis is held in check on Long Island by nematicidal treatment (chiefly with dichloropropene), cultural methods and legal regulation, and the use of resistant varieties of potato in fields where the nematode population remains below the level of discovery (W. F. Mai and M. B. Harrison).

The diffusion of ethylene dibromide through soil was shown by F. Call and N. G. M. Hague to be largely determined by soil porosity; relating chemical to bioassay determinations, they found that very low concentrations persist for long periods. H. W. Nolte found only temporary benefit from using 'Vapam' against Pratylenchus in pine nurseries, and $\mathbf{K}$. Raschke showed that reduction of hatching from Heterodera cysts after treatment with 'Trapex' was due not to delayed hatching but to death of larvæ.

Ultrasonic vibrations, tested by L. Kaempfe, gave disappointing results, especially against encysted Heterodera larvæ.

Radiotracer techniques using phosphorus-32 were applied by B. A. Oteifa and D. M. Elgindi to a study of galling in tomatoes by Meloidogyne javanica and its effect on uptake of nutrient, and by F. Sprau and A. Suesz to indicate that Longidorus maximus feeds on the roots of beet and is thus a parasite; and, using carbon-14, were adapted by B. M. Zuckerman to estimate the amount of plant fluid ingested by $a$ single nematode.

At the biennial general meeting on July 27 members of the Society heard an encouraging report from the secretary, Dr. Lindhardt, who was able to show a steady growth in membership over the years:

1957: 141 members from 19 countries; 1959: 179 from 25 countries; 1961 : 218 from 33 countries (of this last total, 166 come from Europe).

An invitation from Dr. John Grainger to hold the seventh symposium at Auchincruive in September 1963 was accepted with enthusiasm, and Prof. Nolte tabled an advance invitation to Aschersleben for 1965. It was decided to issue to members a duplicated. 'Newsletter' under the editorship of Dr. Lindhardt, assisted by a corps of reporters.

A lavish social programme included a civic reception at the Town Hall, a dinner at the Castle of Laarne, and a lunch at the Park Hotel, Lokeren. There was also a programme of daily excursions for non-participating ladies.

Translator-in-chief, displaying equal facility in the three official languages besides his native Flemish, was Mr. R. Kips (secretary).

B. G. Peters

\section{A NEW LABORATORY FOR RESEARCH ON CREEP}

$\mathrm{O}$ N July 6 the new Creep Laboratory of the British Electrical and Allied Industries Research Association was opened at Leatherhead by Dr. Charles Sykes, managing director of Thomas Firth and John Brown, Ltd. Its purpose is to carry out an extended programme of long-term co-operative research and investigation on the creep of steels in conditions of high temperature and mechanical stress.

Increase in the overall efficiency of generation of electrical power by steam now turns critically on improving the thermodynamic efficiency by operating at higher temperatures and pressures. The limiting factors in practice are set by materials capable of withstanding these conditions during long periods. The highest temperatures (above $600^{\circ} \mathrm{C}$.) are found in superheater tubes, steampipes and control valves, but conditions are even more onerous in turbine rotors, blades and casings where tolerance to distortion is very small.

Historically, progress in steel development has occurred in three phases. Initially, power-station plant was constructed entirely of plain carbon steel; this was followed by the addition of small amounts of alloying elements which added strength to the steel. Now, in the third phase, special highly alloyed stainless steels are being developed. The cost of such steels is high and is reflected in the great increase in the proportion of cost of steam-raising equipment in modern power stations. Such increases must, in the long run, be offset by increased efficiency, and this can only be judged when full knowledge of the life and reliability of these new steels is available. Creep, which can be defined as permanent deformation of materials arising from continued stress, is of basic importance in this connexion.

The investigation of the properties of high-temperdture steels for power stations was inaugurated as long ago as 1930 by the Steels for High Temperature Committee of the Electrical Research Association. Most of the investigations until recently have been carried out by the Metallurgical Division of the National Physical Laboratory and at the National Engineering Laboratory. In 1957 work was started at the Electrical Research Association to supplement that at the National Physical Laboratory. The National Physical Laboratory is, however, no longer able to cope with the vastly expanded programme, and through the joint efforts of the Committee it has been possible to centre all the work in the new buildings and equipment installed at Leatherhead.

The main Laboratory is $140 \mathrm{ft}$. long and $45 \mathrm{ft}$. wide. It has space for about 250 units for testing creep. Since these units dissipate considerable heat it has been necessary to install air-circulating equipment to maintain a suitable ambient temperature for instrumentation and personnel. The bulk of the units are designed to record either the creep or the time of rupture of standard samples cut and very accurately machined from bars of steel or from fabricated parts. At present there are fifty units of high sensitivity fitted with Martens optical extensometers. These machines are designed particularly for studying the creep behaviour of turbine rotor forgings, blades and casings, and are at present also being used for the creep of metal weld deposits and the parent metal. There are fifty large rupture machines, in which ten specimens can be stressed simultaneously end to end. They do not record the creep but only the time to rupture. They are used to provide long-time design data for high-alloy steel steampipes and superheater tubes. The stress applied to the specimens is varied so as to produce rupture times extending from about 300 to $10^{5} \mathrm{hr}$. Graphs of rupturing time against stress are then used 